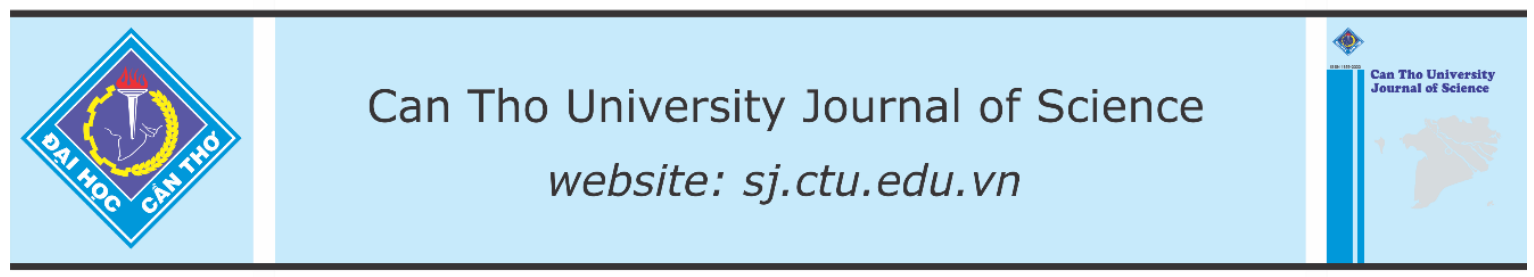

DOI: 10.22144/ctu.jen.2021.009

\title{
Corporate cultural characteristics of startups in developed countries and recommendations for vietnamese small businesses
}

\author{
Nguyen Quang Trung* \\ Faculty of Economics and Business, Hoa Sen University \\ *Correspondence: Nguyen Quang Trung (email: trung.nguyenquang@hoasen.edu.vn)
}

\section{Article info.}

Received 18 Aug 2020

Revised 13 Nov 2020

Accepted 31 Mar 2021

\section{Keywords}

Corporate culture, developed countries, startups

\begin{abstract}
In the situation of globally connected digital economy, changes in organizational structure and smart corporate governance are placing the entrepreneurial structures in the face of unprecedented decisions on building and developing corporate culture. By the method of literature review, desk review on the basis of secondary data is a typical study case on the cultural characteristics of startups in the United States of America (USA), China, Korea, Japan, Singapore and European Union. Based on the experiences from developed countries, some recommendations has been proposed for small business founders in Vietnam. It is expected to contribute an additional perspective on digital business in the era of globalization.
\end{abstract}

\section{INTRODUCTION}

The era of smart industry with "smart companies" and IoT technology (Internet of Things - Internet applications in all fields) has had a strong impact on the corporate management process in our country. Barbosa (2014), Pendolin and Kari (2013), Schein (2012), Szumal and Cooke (2000), Wei et al. (2008) showed that culture is a source of profound impact on the competitive advantage of startups. Meanwhile, scholars such as Neuburger (2018), Radjou and Prabhu (2015) and Ries (2017) agreed that startups in general and especially for smart startups must be continuous and constantly develop the company's culture. The workshops, factories, industrial enterprises to service trade enterprises and latest IDE models are have a micro-culture that connects the past and the present, orients the future (Flamholtz \& Randle, 2011; Schein, 2012). This microculture is an integral part of the macro culture which is the professional culture. By exploring the effect of startup cultural characteristics in the USA, China,
Korea, Japan, Singapore and EU, startup organizations in Vietnam can develop stronger cultures effectiveness.

\section{MATERIALS AND METHODS}

To achieve the goal from an overview of the existing researches on the development of a tech startup culture, learn experience from developed countries and make appropriate recommendations for small businesses in Vietnam, two methods were used: literature review and desk review, specifically:

Literature review was used to identify, synthesize and evaluate scientific research around the culture of startups in the USA, Canada, China, Korea, Japan, Singapore and EU. Forty-five research papers by reputable researchers on the corporate culture characteristics of startups has been selected for analysis and citation involves the construction and application of its nationality, theoretical as well as practical value that it has raised. This article was conducted mainly based on secondary data sources, which are typical studies of foreign authors related 
to the research topic, the works researched and limited to publication time frames from 2000 to 2018 to ensure the freshness of information.

There are three reasons that studies on corporate culture in five developed countries (USA, China, Korea, Japan, Singapore) and EU have been useful. First, these countries have large industrial centers initiate and lead the world in business administration. Next, it has had a lot of research on startup culture so it is very convenient for accessing data and documents. Most importantly, it is the six countries that are Vietnam's largest trading partners so opportunities for cultural exchange and integration are viable.

Desk review has given an overview of the research problem, personal ideas proposed in the form of recommendations for the development of small businesses and this corporate culture in Vietnam. This is a common method for performing an initial assessment of resources. It has been used to uncover sources of information and overview of the research problem. A desk review methodology has been combined with comparative analysis and systematic thinking of clarifying the significance of the research, academic gaps, draw experiences.

\section{RESULTS AND DISCUSSION}

\subsection{Theoretical foundations of corporate culture}

From 2000 to the present, startup culture has often been noted as a shared set of assumptions to guide employee behavior (Dennis, 2001; Dowling, 2001; Schrodt, 2002). Another point of view, Whetten \& Mackey (2002) considers corporate culture as the corporate atmosphere, logo system and identity. Flamholtz \& Randle (2011) think that corporate culture is the personality of the company while Schein (2012) defines corporate culture as a model of shared basic assumptions that the group has learned. When it addresses issues related to adjusting for external fit and internal integration. It is concluded that the company's culture is a total of material and spiritual values that have been created from the establishment and throughout the company's development process.

The classic studies of corporate culture in the West all acknowledge that the structure of culture is a unified system of material values (symbolic systems) and spiritual values (also known as nature). Corporate culture is the sum of two subsets (1) material values and (2) spiritual values with specific characteristics (identity) of the company. The company's culture is from the startup stage, constantly improving in the development process, taking the company as the subject, social environment (customers, customers, partners) and nature (where it operates, supplies of raw materials, the market of consumption) as space and the whole process of existence is a time axis.

Facing a strong startup wave in the Industry revolution 4.0, the corporate culture in this period is increasingly being carefully studied by scientists. Not a pioneer, but Stephen (2016) completely convinced the expert community when pointing out the most basic characteristics of a startup are innovation, startup, and risk-taking. Aulet (2016) recognizes startups as those who create a new business in the form of small and medium-sized businesses (SMEs: they are small businesses in terms of capital, labor or revenue. According to Word Bank (2011), SMEs have from 10 to less than 200 employees and 20 billion VND capital or less, while medium enterprises have 200 to 300 employees with 20 to 100 billion VND capital) or Innovation-Driven Enterprises (IDEs: businesses based on innovative breakthroughs).

However, SMEs or IDEs are often perceived as simple companies in terms of organizational structure and human resource management, limited resources and financial management, manufacturing and technology, the challenges of the company before the business environment and marketing management. It is risky in operations such as the evaluation of Moores \& Yuen (2001), Kallunki \& Silvola (2008), Wang \& Bansal (2012).

\subsection{Cultural characteristics of startups in developed countries}

The era of globalization has created fierce business competition in economies to regional and global markets. It changes the face of the manufacturing and service sector (Boughton, 2002). Many scholars have realized that corporate culture is the force that profoundly influences the competitive advantage of an IDE (Barbosa, 2014; Pendolin \& Kari, 2013; Szumal \& Cooke, 2000; Wei et al., 2008). Pendolin and Kari (2013) assert that the value and profit of the company created today is no longer by mere technology, but it requires constant innovation towards customers, who are the ones who will create new value.

Ries (2017) in his book, "The startup way: How modern companies use entrepreneurial management to transform culture and drive long-term growth" 
points out that successful companies are finding possible ways to replicate their corporate culture if want to continue to grow, and at the same time, the IDEs that desire to succeed will strive to continuously improve the company's culture.

In the 2010s, tech startups changed the traditional theory of corporate culture structure (Craig, 2017; Neuburger, 2018; Radjou \& Prabhu, 2015). By adopting an innovative business-based approach, seeking a breakthrough solution from cultural differences to unprecedented problems, many startups thrive thanking to disrupting traditional lucrative business models (Radjou \& Prabhu, 2015). Craig (2017) asserts that IDEs are changing the rules of corporate culture in an increasingly invisible way, which is completely different from the concept of the previous generation of entrepreneurs.

On the other hand, some characteristics of IDE culture are also pointed out as Studholme (2014) in the famous works "Silicon Valley Startup Companies: A Question of Culture" describing Silicon Valley (USA) almost having the same meaning with IDEs and those companies are defined by culture. This meaningful conclusion was discovered by Studholme (2014) by stumbling upon observations of incorporation in Silicon Valley that statements about IDE establishment are often focused on culture. On the other hand, the importance of lean and customeroriented culture management in IDEs has been noted by Heidi \& Minna (2014). Robinson (2001) also recognizes that leanness is very useful for organizations as they aim to make corporate cultural more innovative.

The USA is the country with the strongest economy in the world, leads the G20 group in entrepreneurship culture (Kegel \& College, 2016). Shaker et al. (2004) base on data from 536 manufacturing companies in the United States to examine the relationship between corporate cultural aspects in familyowned and non-family-owned businesses, the nonlinearity between the cultural dimension of individualism and entrepreneurship has been discovered. The corporate culture is an invaluable asset of IDEs in Silicon Valley, and the willingness to take risks is the advantage of IDE here before the desire to become an entrepreneur (Block \& Keller, 2011). By comparison method, Farley (2018) has shown that corporate culture in the UK focuses primarily on the needs of shareholders and the Board of Directors, while its focus in the US is directed at the customers and employees, corporate culture in the UK to engage employees, while in the US it is used to motivate employees to work hard and be productive.

In Europe, Klaus (2016) recognizes that the startup IDE is extremely innovative, although the number of innovative and high-growth companies in Europe is generally quite small because of empiricism despite the startup centers like London, Berlin, or economic centers like Stockholm and Munich (EY, 2015). From the data of the Global Innovation Index and Social Survey in 27 European countries, Zhu et al. (2018) conducted a study on cultural innovation, a multivariate SEM analysis confirmed that the relationship between Cultural values and innovation performance interact with levels of belief and ideals.

Today, Chinese values are frequently discussed and influential in international business and management documents (Gadner et al., 2015; Zhang, 2007). Chen et al. (2000) note that the Chinese IDE is strongly influenced by traditional culture, companies that are conscious of learning from the outside but at the same time having a very clear awareness about inheriting the tradition. Boontanapibul (2010) in the report "Doing Business in China: Cultural Factors, Startup Concerns, and Professional Development", says there are really many differences in culture, interest in entrepreneurship and development between the USA (strong individualism, medium power gap, for instability will accept risks, short-term orientation) and China (strong collectivism, central power, democratization trend, for instability will avoid risks, long-term orientation).

Korea is a strong startup nation, the successful experience of Korean IDEs based on its own culture has garnered attention and praise from around the world (Choong \& Jennifer, 2014; Gadner et al., 2015). The combination of Western management science and Korean cultural characteristics is considered to be the most effective philosophy (Choong \& Jennifer, 2014). Gadner et al. (2015) evaluated innovation systems in Austria, Israel and Korea and acknowledged the role of a unique Korean IDE culture from the Family-Based Business Model, the model is the "Chaebol" which is a useful reference for modern startups beacause the absolute control of the owners brings a strong consistency in the constant commitment to corporate culture (Hong \& Geon-Cheol, 2008; Rhyu, 2005).

Japan has the most modern and innovative science and technology in the world in the Industry revolution 4.0, so it has always had a profound influence 
on the aspects of science and art of corporate governance through real estate models (Just in Time JIT), Continuous Improvement (Kaizen), Total Quality Management, the quintessence of management in general, and Japanese corporate culture today is the global real reference sources (Kippenberger, 2002; Nakagawa et al., 2018). Kippenberger (2002) says that recognizing Japanese style and spirit, Japanese corporate cultural values were popularized worldwide through the "Seven Spirits of Matsushita" (Seven Spirits of Matsushita) model sated by Konosuke Matsushita (1894-1989) in 1933. Peng (2009) summarized "The Seven Spirits of Matsushita" including service through the industry, fairness, harmony, and cooperation, struggle for progress, courtesy and humility, courtesy and humility, adjustment and assimilation, and gratitude. Some typical IDE studies in Japan such as Kushida (2017) on "Innovation and Entrepreneurship in Japan"; Kegel \& College (2016) compared startup activities between the United States and Japan in many aspects including culture. Noriko et al. (2010) on "High-Tech Startup Management Strategies: Case Studies and Issues in Japan" evaluated the success of startups mostly from a young culture but strong and distinct, not only modern and technological skills, but also preserving the Japanese business tradition.

Lion Island - Singapore has always been considered a model startup ecosystem, an ideal destination for IDEs in the region and around the world (Low, 2009, 2011; Tan, 2015). By investigating and conducting in-depth interviews on core values from Singapore corporate leaders, Low (2009) recorded the top 12 Singaporean companies value as human resources, followed by learning, sense of solidarity, multiethnic/multiculturalism, achievement, globalization and networking, ongoing and resilient efforts, government support and participation, rationalism, realism use, diversity, women's participation. Low (2011) points out that exogenous factors have a strong influence on the development of Singaporean IDE culture, less attention is paid to identity than creativity and integration. Many discussions have noted the Chinese factor in Singapore's startup culture (Tan, 2015), which is easily explained by the Chinese who account for more than $76 \%$ (2015). , they are present in all socio-political levels of Singapore society (Ortmann \& Thompson, 2016).

In the trend of integrating more and more deeply into the world economy, the Government of Vietnam identifies startups as important objects of the economy and the driving force for economic growth. The fact also shows the startup wave is going strong in Vietnam and the number of startups is growing rapidly and these startups can only thrive when it has a strong investment in corporate culture. The analysis of the characteristics of corporate culture will have presented meaningful reference for Vietnam small businesses.

\subsection{Recognition results and recommendations for Vietnamese small businesses}

\subsubsection{Recognition results}

This article has briefly introduced the cultural characteristics in the USA, China, Korea, Japan, Singapore and EU. Experience from the IDEs of USA and EU show that corporate culture is truly an invaluable asset of the IDE that comes from differentiation, a streamlined and digitized structure is a special advantage of IDEs, cultural characteristics IDE USA and EU appreciate creativity and innovation, taking risks. The characteristic of Chinese and Singaporean IDE culture shows traditional culture is the foundation of corporate culture, the corporate culture acquires new values on the one hand, but at the same time the corporate culture must follow value system of traditional culture. Korean and Japanese cultural characteristics suggest that a harmonious combination of East and West based on family cultural identity and national culture is the key to success in building culture, that towards people, people-centered and for human development. Core content is presented in Table 1.

The diverse, colorful picture and theme of IDE culture in developed countries is a useful reference for Vietnamese small businesses on the path of developing corporate culture and asserting their identity. 
Table 1. Corporate cultural characteristics of startups in many developed countries

\begin{tabular}{|c|c|c|}
\hline The nations & Typical research & Core values \\
\hline The United States & $\begin{array}{l}\text { Shaker et al. (2004), Block \& Keller } \\
\text { (2011), Studholme (2014), Kegel \& } \\
\text { College (2016), Farley (2018) }\end{array}$ & \multirow{2}{*}{$\begin{array}{l}\text { Corporate culture is truly an invaluable asset of the } \\
\text { IDE that comes from differentiation, a streamlined } \\
\text { and digitized structure is a special advantage of } \\
\text { IDEs, cultural characteristics IDE USA and EU ap- } \\
\text { preciate creativity and innovation, taking risks }\end{array}$} \\
\hline European Union & $\begin{array}{l}\text { EY (2015), Klaus (2016), Zhu et al. } \\
(2018)\end{array}$ & \\
\hline Chinese & $\begin{array}{l}\text { Chen et al. (2000), Zhang (2007), } \\
\text { Gadner et al. (2015), Boontanapibul } \\
(2010)\end{array}$ & \multirow{2}{*}{$\begin{array}{l}\text { Traditional culture is the foundation of corporate } \\
\text { culture, the corporate culture acquires new values } \\
\text { on the one hand, but at the same time the corporate } \\
\text { culture must follow value system of traditional cul- } \\
\text { ture. }\end{array}$} \\
\hline Singapore & $\begin{array}{l}\text { Low }(2009,2011), \text { Tan }(2015), \text { Ort- } \\
\text { mann \& Thompson }(2016)\end{array}$ & \\
\hline Japan & $\begin{array}{l}\text { Kippenberger (2002), Peng (2009), } \\
\text { Noriko et al (2010), Kegel \& College } \\
\text { (2016), Kushida (2017), Nakagawa } \\
\text { et al. (2018) }\end{array}$ & \multirow{2}{*}{$\begin{array}{l}\text { A harmonious combination of East and West based } \\
\text { on family cultural identity and national culture is } \\
\text { the key to success in building corporate culture, } \\
\text { that towards people, people-centered and for hu- } \\
\text { man development. }\end{array}$} \\
\hline Korea & $\begin{array}{l}\text { Rhyu (2005), Hong and Geon-Cheol } \\
\text { (2008), Choong and Jennifer (2014), } \\
\text { Gadner et al. (2015) }\end{array}$ & \\
\hline
\end{tabular}

\subsubsection{Recommendations for Vietnamese small businesses}

First of all, businesses need to quickly establish a strategy for developing a business culture in the direction of adapting to the new digital age. In general, small companies in Vietnam are more passive with the ongoing digitalization trend, it is very difficult for us to "lead" the Industry Revolution 4.0, the ability to access technology and infrastructure systems are almost very low. Therefore, all companies need to be aware of and build a culture strategy to adapt to the tremendous change that is happening from the completion of infrastructure to information technology applications. The most important future strategies, tactics and plans to adapt to a connected, secure and safe environment to apply smarter and more convenient applications.

Next, administrators need to gradually change the corporate governance method. The impact of the Industry Revolution 4.0 is characterized by smart companies, the Management by Values (MBV) method with the foundation of comprehensive development value, participation, continuous improvement and creativity, consensus and commitment. Thinking that today's administrators need to be aware and practice drastic governance in the direction of MBV, identify values, communicate and thoroughly understand each member, transform values and philosophy into actions and MBV decisions. Also, it is necessary to apply modern quality productivity tools such as 5S - Visual Management (Visual Management), Continuous Improvement Practice
(Kaizen), Green Productivity for management to wasteful screening, productivity improvement and gradually increasing the creative nature (Adhocracy culture) of the corporate culture.

Finally, Vietnamese small companies need to enrich their corporate culture based on acquiring traditional elite values. Companies need to have a clear plan and roadmap in shaping and developing corporate culture based on both "advanced" and "modern", connecting the corporate culture to the source of values. The traditional culture of Vietnam towards people, people-centered and for human development. Effective use of internal marketing will help the company promote the strength of unity and internal unity and contribute to promoting the company's image to the outside.

These recommendations can be useful for startups in Vietnam in general. Whether the startup of commercial and service are the most popular now but the truth is no evidence that it is not confirmed in accordance with the innovation company. These ideas should continue to be observed for the suitability for each type of startup in Vietnam in future studies.

\section{CONCLUSION}

\subsection{Conclusion}

The corporate culture is the force that deeply influences the competitive advantage of an IDE (Barbosa, 2014; Pendolin \& Kari, 2013; Szumal \& Cooke, 2000; Wei et al., 2008). Pendolin \& Kari (2013) find that startups have changed the traditional theory of corporate culture structure (Craig, 
2017; Neuburger, 2018; Radjou and Prabhu, 2015). This study concludes that digital business in the era of globalization is an indispensable trend forcing modern business structures in Vietnam to quickly establish a strategy to develop corporate culture towards adapting to the new era and rich numbers are created by the spirit of innovation, changing the corporate governance method, enriching the company's cultural values on the basis of absorbing traditional elite values. Believing that with the spirit of innovation and legitimate enrichment of the generation of entrepreneurs in the period of international integration, small companies in Vietnam will gradually connect successfully to the global digital economy.

\subsection{Research limitations}

The limitations of this article are limited research capacity and access to data sources. The data and documents used are very limited, mainly the studies in the 2000-2018 period, the studies in 2019 and 2020 have not been updated. The scope of the research is only the USA, China, Korea, Japan, Singapore and EU, referring to the most basic nature of corporate culture without analyzing the differences with individual identity of each company as well as the impacts and the other effects the corporate culture formation. The depth of analysis and discussion are also a limitation of this research because startup culture is a relatively new research issue in Vietnam, it makes the goal of the research only basic sketches. The limitations due to both subjective and objective reasons are a fact, these indicated limitations need to be overcome in coming studies.

\section{REFERENCES}

Aulet, B. (2013). Disciplined Entrepreneurship: 24 Steps to a Successful Startup ( $1^{\text {st }}$ ed). John Wiley and Sons.

Barbosa, E. (2014). Organizational culture oriented for innovation: Influencing Variables. The Matopolska School of Economics in Tarnów Research Papers Collection, 2(25), 7-9.

Block, F. and Keller, M. (2011). State of Innovation The U.S. Government's Role in Technology Development. Paradigm Publishers.

Boontanapibul, C. (2010). Doing Business in China: Cultural Factors, Start-up Concerns and Professional Development. Global Journal of Management and Business Research: B Economics and Commerce, Vol.16, V.1.0 Y, 170-182.

Boughton, J. M. (2002). Globalization and the Silent Revolution of the 1980s. Finance \& Development, 39(1), 40-40. https://www.imf.org/external/pubs/ft/fandd/2002/03/bought.htm.
Chen, X., Bishop, J. W., and Dow S. K. (2000). Teamwork in China: Where Reality Challenges Theory and Practice. Management and Organizations in the Chinese Context, 269-282.

Choong Y. Lee and Jennifer Y. Lee (2014). South Korean Corporate Culture and Its Lessons for Building Corporate Culture in China. The Journal of International Management Studies, 9(2), 33-42.

Craig, W. (2017). How Startups Are Changing the Rules of Office Culture. Forbes https://www.forbes.com/sites/williamcraig/2017/11/03/how-startups-are-changing-therules-of-office-culture/\#797e410e188f.

Dennis, B. B. (2001). Relationships between personal and corporate reputation. European Journal of Marketing, 35(3), 337.

Dowling, G. (2001). Creating Corporate Reputations: Identity, Image and Performance. Oxford University Press.

EY - Ernst and Young (2015). Startup Barometer Deutschland. http://www.ey.com/Publication/vwLUAssets/EY-Start-up-Barometer2015/\$File/EY-Start-up-Barometer-2015.pdf.

Farley, R. (2018). The Differences in Corporate Culture in the U.K. vs. the U.S. https://www.entrepreneur.com/article/319680

Flamholtz, E.G. and Randle, Y. (2011). Corporate Culture: The Ultimate Strategic Asset. Stanford University Press.

Gadner, J., Kim, E.G., Leo, H. (2015). Startup Cultures: A Comparison of the Growing, Importance of HighTech Startups in Austria, Israel and Korea. In book: Designing the future: Economic, societal and political dimensions of innovation. Echomedia Editors (Austrian Council for Research and Technology Development), 200-222.

Heidi, H. and Minna, M. (2014). Lean startup approach for innovative corporate culture. Laurea University of Applied Sciences.

Hong Y. Park and Geon-Cheol Shin (2008). Advantages And Shortcomings Of Korean Chaebols. International Journal of Economics and Business Research, 7(1), 57-65.

Kallunki, J.P. and Silvola, H. (2008). The effect of organizational life cycle stage on the use of activitybased costing. Management Accounting Research, $19,63$.

Kegel, P. and College, R. (2016). A Comparison of Startup Entrepreneurial Activity Between the United States and Japan. Journal of Management Policy and Practice, 17(1), 18-22.

Kippenberger, T. (2002). Leadership styles. Oxford, Capstone Publishing.

Klaus, H. R. (2016). Entrepreneurial culture and start-ups could a cultural shift in favour of entrepreneurship 
lead to more innovative start-ups?. https://www.iwkoeln.de/fileadmin/publikationen/2016/262911/Entrepreneurial_culture_IW_policy_paper.pdf

Kushida, K. (2017). Innovation and Entrepreneurship in Japan: Why Japan (Still) Matters for Global Competition. Stanford Un University.

Low, K. C. P. (2009). Corporate culture and values: Perception of corporate leaders of cooperatives in Singapore $\left(1^{\text {st }}\right.$ ed). VDM-Verlag, Germany.

Low, K.C.P. (2011). Types of Singapore Corporate Culture. Business Journal for Entrepreneurs, 2011(2), 15.

Moores, K. and Yuen, S. (2001). Management accounting systems and organizational configuration: a lifecycle perspective. Accounting, Organizations and Society, 26(4-5), 352.

Nakagawa, K., Nakagawa, M., Fukuchi, H., Sasaki, M., Tada, K. (2018). Japanese Management Styles: to Change or Not to Change? A Subsidiary Control Perspective. Journal of International Business and Economics, 6(2), 7-9.

Neuburger, H. (2018). How innovative companies are leading the way regarding company culture. EU Startup. https://www.eu-startups.com/2018/04/how-innovative-companies-are-leading-the-way-regardingcompany-culture/

Noriko, T., Emiko, T., Tomoyo, K., Haruomi, S. (2010). High-Tech Startup Management Strategies: Case Studies and Issues in Japan ( $1^{\text {st }}$ ed). Toyokeizaishinposha.

Ortmann, S. and Thompson, M, R. (2016). China and the "Singapore Model". Journal of Democracy, 27(1), 40.

Pendolin, H. and Kari, J. (2013). Ulos toimistosta. Reittiopas uusien tuotteiden tekijöille (Out of the office. A route guide for new product makers). Vantaa.

Peng, M.W. (2009). Global Strategy ( $\left.2^{\text {nd }} e d\right)$. Cincinnati: South-Western Cengage Learning.

Radjou, N. and Prabhu, J. (2015). Frugal Innovation How to do better with less. The Economist Newspaper Ltd. 280p.

Rhyu, Sang-young (2015). The Origins of Korean Chaebols and their Roots in the Korean War. The Korean Journal of International Relations, 45(5).

Ries, E. (2017). The startup way: how modern companies use entrepreneurial management to transform culture and drive long-term growth. Crown Publishing Group.

Robinson, M. (2001). The ten commandments of intrapreneurs. New Zealand Management, 49-51.
Schein, E.H. (2012). Organizational Culture and Leadership. Jossey-Bass Publishers: London.

Schrodt, P. (2002). The relationship between organizational identification and organizational culture: Employee perceptions of culture and identification in a retail sales organization. Communication Studies, 53, 189-202.

Shaker A. Z., James C. H., Carlo, S. (2004). Entrepreneurship in Family vs. Non-Family Firms: A Resource-Based Analysis of the Effect of Organizational Culture. Entrepreneurship Theory and Practice (ETP), 28(4), 363-381.

Stephen, J. S. (2016). Fundamentals of Business. Pamplin College of Business and Virginia Tech Libraries.

Studholme, N. E. (2014). Silicon Valley Startup Companies: A Question of Culture. CMC Senior Theses.

Szumal, J. L. and Cooke R. A. (2000). Using the organizational culture inventory to understand the operating cultures of organizations. Handbook of Organizational Culture and Climate. Sage Publications.

Tan, C.S.S. (2015). Start-up Ecosystem in Singapore. https://www.rvo.nl/sites/default/files/2015/03/201503-Start-up-Ecosystem-in-Singapore.pdf

Wang, T. and Bansal, P. (2012). Social Responsibility in New Ventures: Profiting from a Long-Term Orientation. Strategic Management Journal, 33(10), 1135-1153.

Wei, L., Liu, J., Zhang, Y. and Chiu, R. K. (2008). The role of corporate culture in the process of strategic human resource management: Evidence from Chinese Enterprises. Human Resource Management, 47(4), 778.

Whetten, D.A. and Mackey, A, (2002). A Social Actor Conception of Organizational Identity and Its Implications for the Study of Organizational Reputation. Business and Society, 41, 393-414.

World Bank (2011). Small and Medium Enterprises, A Cross-Country Analysis with a New Data Set. http://documents1.worldbank.org/curated/en/967301468339577330/pdf/WPS5538.pdf

Zhang, Z. X. (2007). Barriers to organizational harmony: Mismatch between the values of leaders and employees. Peking UniversityBusiness Review, (1), 24-29.

Zhu, B., Habisch, A. and Thøgersen, J., (2018). The importance of cultural values and trust for innovation - A European study. International Journal of Innovation Management, 22(2), 1-4. 